\title{
Comparison of Calcitonin, Epinephrine and Glucagon Effects on Plasma Membrane Ca-ATPase Activity and Calcium Content in Liver of Rats
}

\author{
Masayoshi YAMAGUCHI \\ Department of Environmental Biochemistry, Shizuoka College of \\ Pharmacy, 2-2-1, Oshika, Shizuoka 422, Japan
}

\begin{abstract}
The effects of calcitonin (CT), epinephrine and glucagon on the plasma membrane Ca-ATPase activity and the calcium content in the liver were investigated $30 \mathrm{~min}$ after a single subcutaneous administration of hormones to rats. Ca-ATPase activity in the plasma membrane fraction was significantly decreased by CT $(80 \mathrm{MRC} \mathrm{mU} / 100 \mathrm{~g}$ $\mathrm{BW})$, while it was not significantly lowered by insulin $(100 \mathrm{mU} / 100 \mathrm{~g} \mathrm{BW})$, epinephrine $(100 \mu \mathrm{g} / 100 \mathrm{~g} \mathrm{BW})$, glucagon $(50 \mu \mathrm{g} / 100 \mathrm{~g} \mathrm{BW})$, or parathyroid hormone $(25 \mathrm{U} / 100 \mathrm{~g}$ $\mathrm{BW})$. The calcium content in the liver was markedly increased by $\mathrm{CT}$, while it was not significantly elevated by epinephrine or glucagon. Meanwhile, the decrease of Ca-ATPase activity in the plasma membrane fraction produced by CT was significantly prevented by simultaneous administration of epinephrine or glucagon, and also the increase in liver calcium was noticeably interfered with. The present results suggests that the action of CT on liver calcium may differ from that of epinephrine or glucagon which causes an increase in cyclic AMP in the liver cells.
\end{abstract}

Calcitonin (CT) produces the increase of calcium in the liver by inhibiting the efflux of calcium (Yamaguchi et al., 1975; Yamaguchi and Yamamoto, 1976), and CT causes the elevation of calcium excretion into the bile of rats (Yamaguchi and Yamamoto, 1978). Recently it has been reported that calcium excretion into bile is increased by various hormones which produce a remarkable elevation of cyclic adenosine 3'5' monophosphate (AMP) in the liver of rats (Yamaguchi, 1979a). However, CT does not causes a significant alteration of adenylate cyclase activity in the liver cells of rat (Canterbury et al., 1974).

Meanwhile, it has been demonstrated that Ca-ATAase in the plasma membrane of cells is involved in the energy-dependent

Received March 23, 1979. pathway for the transport of calcium (Borle, 1967; Moore et al., 1974; Leslie and Borowitz, 1975). More recently it has been found that CT markedly decreases Ca-ATP ase activity in the plasma membrane of rat liver (Yamaguchi, 1979b). Therefore the present study was undertaken to compare CT, epinephrine and glucagon effects on the plasma membrane Ca-ATPase activity and the calcium content in the liver of rats.

\section{Materials and Methods}

\section{Animals}

Male Wistar rats, weighing approximately 110 $130 \mathrm{~g}$, were used in this experiment. They were obtained commercially (Nippon Bio Supp. Center, Tokyo, Japan). The animals were fed commercial lab. chow containing $1.1 \% \mathrm{Ca}$ and $1.1 \% \mathrm{P}$ (Oriental Test Diet, Tokyo, Japan) and tap water freely. 


\section{Hormones}

Calcitonin (lyophilized porcine calcitonin, $68 \mathrm{MRC}$ $\mathrm{U} / \mathrm{mg}$ ) was purchased from Armour Pharmaceutical Company (Kankakee Ill. U.S.A.) Insulin (24.3 I.U./ $\mathrm{mg}$ ), glucagon, epinephrine, and parathyroid hormone $(250 \mathrm{U} / \mathrm{mg}$ ) were purchased from Sigma Chemical Company (St. Louis, Mo., U.S.A.). The hormones were dissolved in demineralized water, and were administered subcutaneously. The vehicle was injected as control. The animals were bled $30 \mathrm{~min}$ after the administration of hormone.

\section{Analytical methods}

Livers were perfused with cold $0.25 \mathrm{M}$ sucrose solution to remove the blood after bleeding. The amount of calcium in the liver was determined by atomic absorption spectrophotometry (Perkin-Elmer, Model 303) after nitric acid digestion.

\section{Membrane preparation}

Livers were removed immediately after perfusion with a cold $0.25 \mathrm{M}$ sucrose solution. The plasma membrane fraction was prepared by a procedure described by Forte et al., (1973). The liver was cut into small pieces and suspended $1: 9$ in $0.25 \mathrm{M}$ sucrose, $0.5 \mathrm{mM} \mathrm{CaCl}, 5 \mathrm{mM}$ Tris- $\mathrm{HCl}$ buffer $(\mathrm{pH}$ 7.4). Optical rupturing of cells was produced by 3540 strokes with a Dounce tight pestle homogenizer. The homogenate was spun at $150 \times g$ in a refrigerated centrif uge for $10 \mathrm{~min}$ and the supernatants were spun at $600 \times g$ for $12 \mathrm{~min}$. The sediments which contained a lot of plasma membrane weve resuspended with a $\mathrm{Ca}^{2+}$-free solution containing $0.25 \mathrm{M}$ sucrose and $5 \mathrm{~mm}$ Tris- $\mathrm{HCl}(\mathrm{pH} 7.4)$ and the suspension was spun at $20000 \times g$ for $10 \mathrm{~min}$. Finally the pellet was suspended in cold demineralized water in order to assay $\mathrm{Ca}$ ATPase activity.

\section{Enzyme assay}

To assay for Ca-ATPase activity, the reaction mixture contained, in a final volume of $1.5 \mathrm{ml}, 30 \mathrm{mM}$ Tris- $\mathrm{HCl}$ buffer ( $\mathrm{pH} 7.4$ ), $10 \mathrm{mM} \mathrm{CaCl}_{2}, 5 \mathrm{~mm} \mathrm{ATP}$ and liver plasma membrane protein $(150-200 \mu \mathrm{g})$. Incubations were carried out in a water-bath at $37^{\circ} \mathrm{C}$ for 10 min during which time the reaction was linear. The reaction was then stopped by quickly placing the tubes in an ice-bath and adding $1 \mathrm{ml} 15 \%(\mathrm{~W} / \mathrm{V})$ $\mathrm{HClO}_{4}$. ATP hydrolysis was measured by the release of inorganic phosphate as determined by the method of Nakamura and Mori (1958). Total protein was determined by the method of Lowry et al., (1951). Ca-ATPase activity was expressed as nmoles Pi released per min per $\mathrm{mg}$ protein.

\section{Statistical methods}

The significance of the difference between the values was estimated by Student's $t$ test. $\mathbf{P}$ value less than 0.05 were considered to indicate statistically significant differences.

\section{Results}

The effects of calcitonin (CT), insulin, epinephrine, glucagon, and parathyroid hormone on Ca-ATPase activity of the plasma membrane fraction in the liver of rats are shown in Table 1 . The administration of $\mathrm{CT}$ ( 40 and $80 \mathrm{MRC} \mathrm{mU} / 100 \mathrm{~g}$ BW) significantly decreased Ca-ATPase activity in the plasma membrane fraction in comparison with that of control. Meanwhile, the administration of insulin (50 and $100 \mathrm{mU} / 100 \mathrm{~g} \mathrm{BW}$ ) or parathyroid hormone (25 U/100 g BW) did not significantly alter Ca-ATPase activity in the plasma membrane fraction when compared with that of control, while the administration of epinephrine (50 and $100 \mu \mathrm{g} / 100 \mathrm{~g} \mathrm{BW}$ ) or glucagon (10 and $50 \mu \mathrm{g} / 100 \mathrm{~g} \mathrm{BW}$ ) slightly but not significantly lowered Ca-ATPase activity.

The effects of CT, glucagon, and epinephrine on Ca-ATPase activity in the plasma membrane fraction and the calcium content in the liver of rats are shown in Table 2. The administration of CT (80 MRC mU/ $100 \mathrm{~g} \mathrm{BW}$ ) caused a significant decrease in Ca-ATPase activity in the plasma membrane fraction and a significant elevation in liver calcium compared with that of the control. The administration of glucagon $(50 \mu \mathrm{g} / 100$ $\mathrm{g} \mathrm{BW})$ or epinephrine $(100 \mu \mathrm{g} / 100 \mathrm{~g} \mathrm{BW})$ slightly but not significantly decreased $\mathrm{Ca}$ ATPase activity in the plasma membrane fraction, and those hormones slightly increased the calcium content in the liver. On the other hand, the simultaneous administration of CT and glucagon, or CT and epinephrine significantly prevented both the decrease in Ca-ATPase activity in the plasma membrane fraction and the increase in liver calcium produced by the administration of CT alone. However, Ca-ATPase activity in the plasma membrane fraction after the simultaneous administration of CT and glucagon, or $\mathrm{CT}$ and epinephrine decreased significantly compared with that of control, 
Table 1. Effects of various hormones on Ca-ATPase activity of plasma membrane frction in the liver cells of rats

\begin{tabular}{|c|c|c|c|}
\hline Treatment & $\begin{array}{l}\text { Dose per } \\
100 \mathrm{~g} \mathrm{BW}\end{array}$ & $\begin{array}{l}\text { Number } \\
\text { of rats }\end{array}$ & $\begin{array}{c}\text { Ca-ATPase activity } \\
(\mathrm{nmol} / \mathrm{min} / \mathrm{mg} \text { protein })\end{array}$ \\
\hline Control & & 9 & $106.3 \pm 8.0$ \\
\hline \multirow{2}{*}{ Calcitonin } & $40 \mathrm{MRC} \mathrm{mU}$ & 5 & $75.8 \pm 6.0 \mathrm{a}$ \\
\hline & $80 \mathrm{MRC} \mathrm{mU}$ & 6 & $67.1 \pm 6.1 \mathrm{a}$ \\
\hline \multirow{2}{*}{ Insulin } & $50 \mathrm{mU}$ & 5 & $117.8 \pm 6.4$ \\
\hline & $100 \mathrm{mU}$ & 5 & $99.7 \pm 2.8$ \\
\hline \multirow{2}{*}{ Epinephrine } & $50 \mu \mathrm{g}$ & 5 & $91.4 \pm 2.6$ \\
\hline & $100 \mu \mathrm{g}$ & 5 & $90.0 \pm 5.1$ \\
\hline \multirow{2}{*}{ Glucagon } & $10 \mu \mathrm{g}$ & 5 & $89.8 \pm 2.3$ \\
\hline & $50 \mu \mathrm{g}$ & 5 & $88.7 \pm 2.7$ \\
\hline Parathyroid hormone & $20 \mathrm{U}^{\circ}$ & 5 & $107.4 \pm 7.5$ \\
\hline
\end{tabular}

Values are mean \pm SE. The rats were bled $30 \mathrm{~min}$ after the administration of hormones or vehicle. a: $\quad \mathbf{P}<0.01$ as compared with control.

Table 2. Effects of calcitonin (CT), glucagon, and epinephrine on Ca-ATPase activity in the plasma membrane fraction and the calcium content in the liver of rats

\begin{tabular}{lccc}
\hline \hline Treatment & $\begin{array}{c}\text { Number } \\
\text { of rats }\end{array}$ & $\begin{array}{c}\text { Ca-ATPase activity } \\
(\mathrm{nmol} / \mathrm{min} / \mathrm{mg} \text { protein })\end{array}$ & $\begin{array}{c}\text { Liver calcium } \\
(\mu \mathrm{g} / \mathrm{g} \text { wet })\end{array}$ \\
\hline Control & 5 & $104.8 \pm 7.9$ & $11.6 \pm 0.8$ \\
CT & 5 & $64.5 \pm 3.6 \mathrm{a}$ & $22.6 \pm 1.6 \mathrm{a}$ \\
Glucagon & 5 & $89.1 \pm 3.8$ & $15.3 \pm 1.1$ \\
Epinephrine & 5 & $91.5 \pm 4.9$ & $14.8 \pm 1.4$ \\
CT+glucagon & 6 & $76.0 \pm 1.0 \mathrm{a}, \mathrm{b}$ & $17.6 \pm 1.4 \mathrm{a}, \mathrm{b}$ \\
CT +epinephrin & 6 & $81.9 \pm 2.2 \mathrm{a}, \mathrm{b}$ & $16.2 \pm 1.2 \mathrm{a}, \mathrm{b}$ \\
\hline
\end{tabular}

Values are mean \pm SE. CT $(80 \mathrm{MRC} \mathrm{mU} / 100 \mathrm{~g} \mathrm{BW})$, glucagon $(50 \mu \mathrm{g} / 100 \mathrm{~g} \mathrm{BW})$, and epinephrine $(100 \mu \mathrm{g} / 100 \mathrm{~g} \mathrm{BW})$ was administered subcutaneously. Glucagon or epinephrine was administered immediately after the treatment of CT. The rats were bled $30 \mathrm{~min}$ after the administration of vehicle, CT, glucagon or epinephrine.

a: $\mathbf{P}<0.01$ as compared with control.

b: $\mathrm{P}<0.01$ as compared with CT.

while the calcium content in the liver increased significantly.

\section{Discussion}

Calcitionin (CT) increases calcium accumulation in the liver cells by inhibiting the efflux of intracelluar calcium in rats (Yamaguchi et al., 1975; Yamaguchi and Yamamoto, 1976). Recently it has been demonstrated that Ca-ATPase in the plasma membrane is involved in the energy-dependent pathway for the efflux of intracellular calcium into the extracellular fluid from the cells (Borle, 1967; Moore et al., 1974; Leslie and Borowitz, 1975). More recently it has been found that CT causes a significant decrease in Ca-ATPase activity in the plasma membrane fraction of the liver cells and a corresponding elevation of liver calcium (Yamaguchi, 1979b). From this result, it is suggested that the effect of CT in increasing liver calcium may be caused by the lessening of Ca-ATPase activity in the plasma membrane by CT (Yamaguchi, 1979b).

In the present studies, the author compared CT, epinephrine and glucagon effects on the plasma membrane Ca-ATPase acti- 
vity and the calcium content in the liver of rats. It was found that CT markedly decreased Ca-ATPase activity in the plasma membrane, while insulin, epinephrine, glucagon, and parathyroid hormone did not significantly reduce the plasma membrane Ca-ATPase activity. These results indicate that the effect of CT on Ca-ATPase in the plasma membrane of rat liver is specific compared with those of insulin, epinephrine, glucagon and parathyroid hormone. It was also found that glucagon or epinephrine significantly prevented the decrease in Ca-ATPase activity in the plasma membrane fraction and the increase of calcium content in the liver produced by CT. These results further support the view that the mode of action of $\mathrm{CT}$ on liver calcium differs from that of glucagon or epinephrine.

Glucagon, epinephrine, and cyclic AMP participates in the regulation of hepatic cellular homeostasis of calcium ( $R$ asmussen and Tenenhouse, 1968; Berridge, 1976; keppens et al., 1977). It was previously reported that glucagon or epinephrine, like CT, increases the excretion of calcium into the bile, suggesting that the increase in bile calcium excretion caused by glucagon or epinephrine may be induced by the alteration of calcium flux related to cyclic AMP in the liver cells (Yamaguchi, 1979a). However, epinephrine and glucagon markedly increase adenylate cyclase activity in the liver cells of rats, while CT does not increase it
(Canterbury et al., 1974). The action of CT on liver calcium is not dependent on cyclic AMP (Yamaguchi et al., 1975). Epinephrine and glucagon do not alter Ca-ATPase activity in the plasma membrane of the liver cells, although CT decreases markedly. Accordingly, the action of CT on calcium regulation in the liver cells may differ from that of epinephrine and glucagon.

\section{References}

Berride, M. J. (1976). Adv. Cyclic Nucleotide Res. $6,1$.

Borle, A. B. (1967). Clin. Orthop. Relat. Res. 52, 267. Canterbury, J. M., G. Lery, E. Ruiz and E. Reiss (1974). Proc. Soc. Exp. Biol. Med. 147, 366.

Forte, J. G., T. M. Forte and E. Heinz (1973). Biochim. Biophys. Acta 298, 827.

Keppens, S., J. R. Vandenheede and H. DeWulf (1977). ibid. 394, 227.

Lowry, O. H., N. J. Rosebrough, A. L. Farr and R. J. Randall (1951). J. Biol. Chem. 193, 265.

Moore, L., D. F. Fitzpatrick, T. S. Chen and E. J. Landon (1974). Biochim. Biophys. Acta 345, 405.

Nakamura, M. and K. Mori (1958). Nature (London), 182, 1141.

Rasmussen, H. and A. Tenenhouse (1968). Proc. Nat. Acad. Sci., 59, 1364.

Yamaguchi, M., Y. Takei and T. Yamamoto (1975). Endocrinology 96, 1004.

Yamaguchi, M. and T. Yamamoto (1976). Chem. Pharm. Bull. (Tokyo), 24, 159.

Yamaguchi, M. and T. Yamamoto (1978). ibid. (Tokyo), 26, 1981.

Yamaguchi, M. (1979a). Endocrinol. Japon. 26, 111. Yamaguchi, M. (1979b). Endocrinol. Japon. 26, 605. 